\title{
Okul Öncesi Eğitim Kurumlarına Devam Eden 5-6 Yaş Grubu Çocukların Yeme Davranışları ile Anne-Baba İlgi Düzeyi Arasındaki İlişkinin İncelenmesi
}

\section{Examination of the Relationship Between Eating Behaviors of 5-6 Years Old Children Attending Pre- School Institutions and Mother-Father Child Care Level}

\author{
Nur Betül KARAASLAN* (iD, Hülya BİLGİN (iD
}

\section{ÖZ}

Amaç: Araştırma, okul öncesi eğitim kurumlarına devam eden 5-6 yaş okul öncesi dönem çocuklarının ebeveynlerinden alınan veriler doğrultusunda, çocukların yeme davranışları ile anne-babaların ilgi düzeyleri arasındaki ilişkinin incelenmesini amaçlamaktadır.

Yöntem ve Araçlar: Araştırmanın örneklemini 2017-2018 eğitim öğretim yılında İstanbul ili Milli Eğitim Bakanlığı́na bağlı özel / resmi okul öncesi eğitim kurumlarına devam eden, 5-6 yaş grubu 357 çocuğun anne ve babaları oluşturmaktadır. İlişkisel tarama yöntemi kullanılmıştır. Çocukların ve ailelerinin demografik özelliklerini belirlemek için araștırmacı tarafından hazırlanan "Kişisel Bilgi Formu", çocukların yeme davranıșlarını belirlemek için Lynda A. Archer, Peter L. Rosenbaum ve David L. Streiner (1990) tarafından geliştirilen ve Ünlü (2011) tarafından Türkçeye çevrilerek geçerlik güvenirlik çalışması yapılan 'Çocuklarda Yeme Davranışı Değerlendirme Ölçeği' kullanılmıştır. Çocukların anne-babalarının ilgi düzeyini belirlemek için Sucuoğlu, Özkal, Yıldız-Demirtaş ve Güzeller (2015) tarafından geliştirilen “Çocuğa Yönelik Anne-Baba İlgisi Ölçeğì" kullanılmıştır.

Sonuçlar: Araştırma sonuçlarına göre; çocuklarda Yeme Davranışı Değerlendirme Ölçeği ile Çocuğa Yönelik Anne-Baba İlgisi Ölçeği anne formu arasında "düşük" bir ilişki bulunmuştur. Çocuklarda Yeme Davranışı Değerlendirme Ölçeği ile Çocuğa Yönelik Anne-Baba İlgisi Ölçeği baba formu arasında ise; sadece okula yönelik ilgi alt boyutu ile davranış alt boyutu arasında anlamlı bir ilişki olduğu görülmektedir.

Anahtar Kelimeler: Okul Öncesi Dönem Çocuğu, Çocukta Yeme Davranışı, Anne-Baba İlgisi

\section{ABSTRACT}

Purpose: The research aims to examine the relationship between the eating behaviours of 5-6 years old children and the parents' child care levels with the data obtained from the parents of 5-6 years old preschool children.

Method and Materials: The sample of the study consists of mothers and fathers of 357 children in the 5-6 age group who attend private / public preschool education institutions affiliated to the Ministry of National Education in Istanbul in 2017-2018 academic year. In the research, relational screening method was used. The "Personal Information Form" prepared by the researcher in order to find, children and parents' demographic characteristics, and "Children Eating Behaviour Evaluation Scale" prepared by Lynda A. et al. (1990) and translated by Ünlü (2011) in order to find children eating behaviour used in the research. "Mother-Father Child Care Scale" created by Sucuoğlu, Özkal, Ylldız-Demirtaş and Güzeller (2015) was used in the research in order to determine mother-father child care scale.

Results: Similarly, there are significant differences in mother-father child care with child age, type of educational institution, age of the father, parents' education level, the mother's employment status, the birth order of child in the family and the marital status of parent. It is observed that there is a "low" correlation between the Child Eating Behavior Evaluation Scale and the Mother-Father Child Care Scale. Between the Child Eating Behavior Evaluation Scale and the Mother-Father Child Care Scale for the father; it is observed that there is a positive "low" level correlation in child sub-dimension school interest with mother's sub-dimension opinion about child's eating behavior.

Keywords: Pre-school Child, Child Eating Behaviour, Mother-Father Child Care

* İstanbul Okan Üniversitesi

Sorumlu Yazar/Correspondence Author: Nur Betül KARAASLAN

E-posta/E-mail: betul.karaaslan@hotmail.com

Geliş Tarihi/Received: 23.02.2021

Kabul Tarihi/Accepted: 12.05 .2021

Ç. Yayınlanma Tarihi/Online Published: 31.05.2021 


\section{GİRIŞ}

Sağlıklı bir şekilde büyüyen nesiller, sağlıklı bir geleceğin temelini oluşturur. Çocukların gelişimlerini destekleyen ve onları eğitim hayatına hazırlayan okul öncesi dönem, ileriki yaşlara da yön vereceğinden yaşamın en önemli dönemidir (Kahraman, 2019). Okul öncesi dönem; sıfır-altı yaşı kapsayan, çocuğun yaşadığı çevre ile yeni yeni tanıştığı, oyun ve taklit yolu ile çevresindekilerden roller benimsediği bir dönemdir (Arlı, Şanlıer, Küçükkömürler ve Yaman, 2017).

Okul öncesi dönemde yaşamsal öneme sahip, büyüme ve gelişmeyi etkileyen en önemli faktör beslenmedir (Çelikoyar, 1988). Yaşamın sürdürülebilmesi, büyüme, gelişme ve sağlığın korunabilmesi için besin alınması ve alınan besinlerin organizmada kullanılması beslenme olarak tanımlanır (Garipağaoğlu, Saydam ve Gökçay, 2003). Bireyler bu temel ihtiyaçlarını karşılarken çeşitli yeme davranışları ve tutumları sergilerler (Karakuş, Yıldırım ve Büyüköztürk, 2016). Bu dönemde çocuklar, davranışları taklit yolu ile öğrendiği gibi besin alımını da taklit ederler. Anne-babaların hangi besinleri tükettiğini, hangi besinleri reddettiğini gözlemlerler, yani ailedeki bireylerin davranışları paralelinde çocuk da davranış kazanır. Anne-babaların ve çevresindeki kişilerin davranışları, önemsememe, zorlama gibi etkenler çocuğun beslenme davranışlarını etkilemektedir (Arlı ve diğerleri, 2017). Bu yüzden ailenin ve çevrenin çocuğun her davranışı kazanmasında olduğu gibi yeme davranışında da etkili olduğu düşünülebilir.

Aynı zamanda aile, çocuğun ilk sosyalleşme deneyimlerini yaşadığı kurumdur. Çocuğa karşı sergilenen davranış ve tutumlar, ilk yaşantıların temelini oluşturacağından büyük bir öneme sahiptir (Yavuzer, 2011). Anne-babaların hem birbirlerine hem de çocuklarına yönelik ilgi, tutum, davranış, iletişim ve aralarındaki ilişki sağlıklı çocuklar yetiştirmek için önemlidir (Ak, 2018). Bahsedildiği gibi çocukların sağlıklı bir şekilde gelişebilmesi için fiziksel olduğu kadar duygusal ihtiyaçlarının da giderilmesi önemlidir. Çocuk ile zaman geçirmek, ilgi göstermek ve sevgiyi hissettirmek duygusal gelişimlerini desteklemektedir (Öztürk, 2007). Yapılan çalışmalar incelendiğinde anne-baba ilgisinin çocuğu davranışsal ve akademik yönden etkilediği görülmektedir. Anne-baba ilgisinin öğrenim düzeyi, sosyo-ekonomik durum, kültür fark etmeksizin çocuğun olumlu davranış geliştirmesinde, akademik başarısında, özgüveninde, sosyal ve iletişim becerilerinde ve olumlu arkadaş ilişkilerinde etkili olduğu görülmektedir (Englund ve diğerleri, 2004; Fan ve Chen, 2001; Hill ve Craft 2003; Jeynes 2007; Kim, 2002).

Okul öncesi dönem çocuklarının yemek yemeyi düzenli bir alışkanlık haline getirebilmelerinde ailenin tutumu büyük önem taşımaktadır (Köroğlu, 2009), çünkü bu dönemde çocuklar gıda alımının yapılandırılmasında hala anne-babalarına bağımlıdırlar (Ek, 2016). Çocuklar, hayatları boyunca izlerini taşıyacakları sosyo-kültürel değerleri ve beslenme alışkanlıklarını aileden edinir. Dolayısı ile çocuğun yeme alışkanlığını, ailenin yaşam biçimine bakarak değerlendirmek mümkündür (Wisner, 1996). Diğer yandan anne-baba ilgisinin çocuğu davranışsal ve akademik yönden etkilediği vurgulanmaktadır (Chen ve Fan 2001; Craft ve Hill 2003; Englund ve diğerleri, 2004; Jeynes, 2007; Kim, 2002). Bu durumda çocuğun ilk çevresini oluşturan anne-babaların ilgilerinin, çocuğun temel gereksinimlerinden biri olan yeme davranışı üzerinde etkili olabileceği düşünülmektedir. Bu araştırmanın temel amac1, 5-6 yaş çocuklarının ebeveynlerinin gözlem ve görüşlerine göre çocukların yeme davranışları ile anne-baba ilgisi arasındaki ilişkiyi incelemektir.

Anne-babaların çocuk üzerinde ve çocuklarda gelişecek davranışlar üzerinde yadsınamaz bir etkisi olduğu düşünüldügünde, çocukların yeme davranışları ile anne - babaların ilgi düzeyleri arasında ilişki olabileceği düşünülmektedir. Alanyazında yeme davranışı ile ilgili çalışmalar bulunmasına rağmen yeme davranışının anne-baba ilgisi ile arasındaki ilişkiyi inceleyen çalışma bulunmamaktadır. Bu nedenle araştırmanın alanyazına katkı sağlayacağı düşünülmektedir. Araştırma sonuçlarının; anne-babalara ve anne-baba ilgisinin çocuğun yeme davranışlarına etkileri hakkında çalışma yapacaklara katkı sağlayacağı düşünülmektedir.

\section{YÖNTEM}

\section{Araştırma Modeli}

Okul öncesi eğitim kurumlarına devam eden 5-6 yaş çocuklarının yeme davranışları ile anne-baba ilgi düzeyleri arasındaki ilişkinin incelenmesini amaçlayan bu araştırmada ilişkisel tarama modeli kullanılmıştır. 


\section{Evren - Örneklem}

Araştırmanın ulaşlabilir evrenini, İstanbul'un Bahçelievler, Güngören, Gaziosmanpaşa ve Küçükçekmece ilçelerinden rastgele seçilen özel ve devlet anaokullarına 2017-2018 eğitim-öğretim yılında devam eden 5-6 yaş çocuklarının ebeveynleri oluşturmaktadır. Örneklemini ise araştırma amacına en iyi hizmet edeceği düşünülen en uygun kişilerin dikkate alındığı (Baştürk ve Taştepe, 2013) bu evrenden "amaçlı örnekleme yöntemi" ile seçilen ve gönüllülük formunu onaylayan 357 çocuğun ebeveynleri oluşturmuştur. Araştırmanın çalışma grubuna ilişkin demografik bilgiler Tablo1'de sunulmuştur.

Tablo 1. Örneklemim Demografik Bilgilerine Yönelik Frekans ve Yüzde Dağılımı

\begin{tabular}{|c|c|c|c|}
\hline Özellik & Gruplar & $f$ & $\%$ \\
\hline \multirow[t]{2}{*}{ Çocuğun cinsiyeti } & $\mathrm{K} 1 \mathrm{Z}$ & 152 & 42,6 \\
\hline & Erkek & 205 & 57,4 \\
\hline \multirow{2}{*}{ Çocuğun yaşı } & 5 yaş & 209 & 58,5 \\
\hline & 6 yaş & 148 & 41,5 \\
\hline \multirow{2}{*}{ Kurum türü } & Özel okul & 184 & 51,5 \\
\hline & Devlet okulu & 173 & 48,5 \\
\hline \multirow[b]{3}{*}{ Annenin yaşı } & $21-30$ yaş & 75 & 21,0 \\
\hline & $31-40$ yaş & 225 & 63,0 \\
\hline & 41 yaş ve üzeri & 57 & 16,0 \\
\hline \multirow{3}{*}{ Babanın yaşı } & 21-30 yaş & 30 & 8,4 \\
\hline & 31-40 yaş & 201 & 56,3 \\
\hline & 41 yaş ve üzeri & 126 & 35,3 \\
\hline \multirow{6}{*}{ Annenin öğrenim düzeyi } & Okuryazar & 24 & 6,7 \\
\hline & Ortaokul mezunu & 41 & 11,5 \\
\hline & Lise mezunu & 122 & 34,2 \\
\hline & Ön lisans mezunu & 47 & 13,2 \\
\hline & Lisans mezunu & 99 & 27,7 \\
\hline & Lisansüstü mezunu & 24 & 6,7 \\
\hline \multirow{6}{*}{ Babanın öğrenim düzeyi } & Okuryazar & 14 & 3,9 \\
\hline & Ortaokul mezunu & 44 & 12,3 \\
\hline & Lise mezunu & 125 & 35,0 \\
\hline & Ön lisans mezunu & 24 & 6,7 \\
\hline & Lisans mezunu & 110 & 30,8 \\
\hline & Lisansüstü mezunu & 40 & 11,2 \\
\hline \multirow{2}{*}{$\begin{array}{l}\text { Annenin bir iş yerinde } \\
\text { çalışma durumu }\end{array}$} & Çalışıyor & 117 & 32,8 \\
\hline & Çalışmiyor & 240 & 67,2 \\
\hline \multirow{3}{*}{ Ailenin aylık gelir durumu } & $1500 \mathrm{tl}$ ve altı & 15 & 4,2 \\
\hline & $1501-2999 \mathrm{tl}$ & 107 & 30,0 \\
\hline & 3000 tl ve üzeri & 235 & 65,8 \\
\hline \multirow{3}{*}{$\begin{array}{l}\text { Ebeveynlerin medeni } \\
\text { durumları }\end{array}$} & Evli & 344 & 96,4 \\
\hline & Boşanmış & 12 & 3,4 \\
\hline & Diğer & 1 & ,3 \\
\hline Toplam & & 357 & 100,0 \\
\hline
\end{tabular}

Tablo 1 incelendiğinde çalışma grubunu oluşturan çocukların \%57,4'ünün erkek, \%42,6'sının kız; eğitim gördükleri kurumların \%51,5’inin özel okul, \%48,5’inin devlet okulu olduğu görülmektedir. Çalışma grubunda yer alan çocukların annelerinin (\%63) ve babalarının (\%56,3) çoğunluğu 31-40 yaş arasındadır. Öğrenim düzeyleri incelendiğinde hem annelerin hem de babaların (sırasıyla; \%34,2 ve \%35) çoğunlukla lise mezunu oldukları; annelerin \%67,2'sinin çalışmadığı; ailelerin aylık gelirlerinin çoğunlukla $(\% 65,8) 3.000$ tl ve üzeri olduğu görülmektedir. Anne-babaların $\% 96,4$ 'ü evlidir.

Örneklem grubunda yer alan 357 çocuğun ikisinin annesi, üçünün babası Çocuğa Yönelik Anne-Baba İlgi 
Ölçeğindeki ilgili kısımları işaretlememişlerdir. Bu nedenle Tablo 3, 4, 5 ve 6’da araştırmaya katılan anne sayısı 355, baba sayısı ise 354'dür. Bunun nedeni kişisel bilgi formunda yer alan medeni durum farklılıkları ve çalışmaya dahil olduktan sonra formdaki sorulara cevap almakta zorlanmamız kaynaklı olduğu düşünülmektedir.

\section{VERİ TOPLAMA ARAÇLARI VE ANALIZİ}

Araştırmaya dahil olmaları için seçilen katılımcılara araştırmanın amacı, içeriği ve uygulanacak ölçekler ile ilgili bilgi verilmiş, yazılı olarak da gönüllülük onamları alınmıştır.

Araştırmada üç farklı veri toplama aracı kullanılmıştır:

Kişisel Bilgi Formu: Araştırmacı tarafından hazırlanan bu form; çocuğun cinsiyeti, çocuğun yaşı, çocuğun okul öncesi eğitimi aldığı kurumun türü, annenin yaşı, babanın yaşı, annenin öğrenim düzeyi, babanın öğrenim düzeyi, annenin çalışma durumu, ailenin aylık gelir durumu, anne-babanın medeni durumu hakkında bilgi almayı amaçlayan 10 sorudan oluşmaktadır.

Çocuklarda Yeme Davranışı Değerlendirme Ölçeği; Archer, Rosenbaum ve Streiner tarafından (1990), Kanada'da geliştirilmiş olan bu ölçek hem normal gelişim gösteren hem de otizm tanısı konmuş 2-12 yaş grubu çocukların yeme davranışlarını değerlendirmeyi amaçlamaktadır. Çocukluk çağı yeme ve yemek zamanı problemlerine yönelik oluşturulmuş 40 maddelik bu ölçek, ebeveynler tarafından doldurulacak şekilde hazırlanmıştır. Ünlü (2011) tarafından uyarlanan bu ölçeğin çalışma grubunu 4-6 yaş dönemi okul öncesi eğitim kurumlarına devam eden 322 normal çocuk ve yaygın gelişim bozukluğu olan 24 çocuk oluşturmuştur. Ölçek iki alt boyuttan ve 40 maddeden oluşmaktadır. Birinci alt boyut olan "olumlu yeme davranışları" nın cronbach alpha katsayısı ,790; ikinci alt boyut olan "olumsuz yeme davranışları” nın cronbach alpha katsayısı ,680 dir.

Çocuğa Yönelik Anne-Baba İlgisi Ölçeği; Bu ölçek; Sucuoğlu, Özkal, Yıldız-Demirtaş ve Güzeller tarafından (2015) anne-babaların (okul öncesi eğitim kurumlarına devam eden 4-6 yaş çocuğu olan) çocuklarına yönelik ilgi düzeylerini belirlemek amacıyla geliştirilmiştir. Anne ve babalara yönelik 2 farklı form şeklinde hazırlanmıştır. 5'li likert tipi ölçeğin cevap seçenekleri çok sık (1), sık (2), bazen (3), az (4), hiç (5) şeklindedir.

Geçerlik çalışması kapsamında yapılan faktör analizi sonucunda Ölçeğin Anne İlgi Formu 34 madde ve 4 alt boyuttan, Baba İlgi Formu ise 40 madde ve 3 alt boyuttan oluşmaktadır. Anne İlgi Formunun 4 alt boyutu Kontrole Yönelik İlgi, Davranış Geliştirmeye Yönelik İlgi, Okula Yönelik İlgi, İlgileri Geliştirmeye Yönelik İlgi olarak belirlenmiştir. Baba İlgi Formunun 3 alt boyutu ise Davranış Geliştirmeye Yönelik İlgi, Kontrole Yönelik İlgi, Okula Yönelik İlgi olarak saptanmıştır.

Güvenilirlik çalışması kapsamında hesaplanan Cronbach Alpha katsayıları Anne İlgi Formu’nun toplamı için .91, Baba İlgi Formu’nun toplamı için .94 bulunmuştur. Ölçeğin Anne İlgi Formu’nun Kontrole Yönelik İlgi alt boyutu için Cronbach Alpha katsayıs1 .88, Davranış Geliştirmeye Yönelik İlgi alt boyutu için .87, Okula Yönelik İlgi alt boyutu için .76, İlgileri Geliştirmeye Yönelik İlgi alt boyutu için .77 olarak hesaplanırken Baba İlgi Formu’nun Kontrole Yönelik İlgi alt boyutu Cronbach Alpha katsayısı .89, Davranış Geliştirmeye Yönelik İlgi alt boyutu için .94, Okula Yönelik İlgi alt boyutu için .85 bulunmuştur (Sucuoğlu, Özkal, Yıldız-Demirtaş ve Güzeller, 2015).

Araştırmada 5-6 yaş çocuklarının ebeveynlerinin gözlem ve görüşlerine göre çocukların yeme davranışları ile ilgili anne-baba ilgileri arasındaki ilişkileri belirlemek amacıyla Pearson Korelasyon analiz tekniği kullanılmıştır.

Araştırma için gerekli etik kurul onayı Okan Üniversitesi Lisansüstü Eğitim Enstitüsü tarafından alınmıştır.

\section{BULGULAR}

Araştırmaya katılan 5-6 yaş grubu çocukların yeme davranışları ile anne-baba ilgileri arasındaki ilişkiye ve demografik bilgilerin yeme davranışları ve anne-baba ilgisine göre dağılımlarına ait bulgular bu kısımda yer almaktadır. 
Tablo 2. Çocuklarda Yeme Davranışı Değerlendirme Ölçeğinden Alınan Puanların Ortalama ve Standart Sapma Değerleri

\begin{tabular}{llllll}
$\begin{array}{l}\text { Ölçeğin Alt } \\
\text { Boyutları }\end{array}$ & $\mathbf{N}$ & Min & Max & Ort & SS \\
\hline $\begin{array}{l}\text { Olumlu Yeme } \\
\text { Davranışı }\end{array}$ & 357 & 1,57 & 5,00 & 3,64 &, 58 \\
$\begin{array}{l}\text { Olumsuz Yeme } \\
\text { Davranışı }\end{array}$ & 357 & 1,00 & 3,60 & 1,94 &, 46 \\
\hline Toplam & 357 & 1,69 & 3,73 & 2,79 &, 30 \\
\hline
\end{tabular}

Tablo 2 incelendiğinde ölçeğin Olumlu Yeme Davranışı alt boyutundan alınan puanların en düşük 1,57, en yüksek 5,00 olduğu ve bu alt boyuttan alınan ortalama puanların orta düzeyde $(3,64)$ olduğu görülmektedir. Olumsuz Yeme Davranışı alt boyutundan alınan puanlar en düşük 1,00, en yüksek 3,60'dır. Bu alt boyuttan alınan ortalama puanların ise düşük düzeyde $(1,94)$ olduğu görülmektedir.

Tablo 3. Çocuğa Yönelik Anne-Baba İlgisi Ölçeği Anne Formundan Alınan Puanların Ortalama ve Standart Sapma Değerleri

\begin{tabular}{llllll} 
Ölçeğin Alt Boyutları & N & Min & Max & Ort & SS \\
Kontrole Yönelik İlgi & 355 & 1,00 & 5,00 & 1,51 &, 43 \\
DavranışG Geliştirmeye Yönelik İlgi & 355 & 1,00 & 5,00 & 1,52 &, 54 \\
Okula Yönelik İlgi & 355 & 1,00 & 5,00 & 2,50 &, 87 \\
İlgileri Geliştirmeye Yönelik İlgi & 355 & 1,00 & 5,00 & 2,24 &, 82 \\
\hline Toplam & 355 & 1,00 & 5,00 & 1,94 &, 50 \\
\hline
\end{tabular}

Tablo 3 incelendiğinde Çocuğa Yönelik Anne-Baba İlgisi Ölçeği Anne Formu’nun tümünden ve alt boyutlarından alınan ortalama puanların düşük olduğu görülmektedir. Ortalama puanlar; Kontrole Yönelik İlgi alt boyutu için 1,51, Davranış Geliştirmeye Yönelik ilgi alt boyutu için 1,52, Okula Yönelik İlgi alt boyutu için 2,50 ve İlgileri Geliştirmeye Yönelik İlgi alt boyutu için 2,24'tür.

Tablo 4. Çocuklara Yönelik Anne-Baba İlgisi Ölçeği Baba Formundan Alınan Puanların Ortalama ve Standart Sapma Değerleri

\begin{tabular}{llllll} 
Ölçeğin Alt Boyutları & $\mathbf{N}$ & Min & Max & Ort & SS \\
Kontrole Yönelik İlgi & 354 & 1,00 & 5,00 & 2,19 &, 72 \\
$\begin{array}{lllll}\text { Davranış Geliştirmeye } \\
\text { Yönelik İlgi }\end{array}$ & 354 & 1,00 & 5,00 & 2,10 &, 73 \\
Okula Yönelik İlgi & 354 & 1,00 & 5,00 & 3,42 &, 82 \\
\hline Toplam & 354 & 1,00 & 5,00 & 2,57 &, 64 \\
\hline
\end{tabular}

Tablo 4 incelendiğinde ölçeğin Baba Formu’nun Kontrole Yönelik İlgi alt boyutundan alınan ortalama puanlar $(2,19)$ ile Davranış Geliştirmeye Yönelik İlgi alt boyutundan alınan ortalama puanların $(2,10)$ düşük düzeyde; Okula Yönelik İlgi alt boyutundan alınan ortalama puanların $(3,42)$ ise orta düzeyde olduğu görülmektedir.

Tablo 5. Çocuklarda Yeme Davranışı Değerlendirme Ölçeği ile Çocuğa Yönelik Anne-Baba İlgisi Ölçeği Anne Formu Puanları Arasındaki İlişki

\begin{tabular}{|c|c|c|c|c|c|}
\hline \multicolumn{6}{|c|}{ Pearson } \\
\hline \multicolumn{2}{|l|}{ Alt Boyutlar } & $\begin{array}{l}\text { Kontrole Yönelik } \\
\text { İlgi }\end{array}$ & $\begin{array}{l}\text { Davranış } \\
\text { Geliştirmeye } \\
\text { Yönelik İlgi }\end{array}$ & Okula Yönelik İlgi & $\begin{array}{l}\text { İlgileri Geliştirmeye } \\
\text { Yönelik İlgi }\end{array}$ \\
\hline \multirow{3}{*}{ Olumlu Yeme Davranışı } & $\mathrm{R}$ &,$- 123^{\star}$ &,- 013 & , 102 & ,032 \\
\hline & $\mathrm{P}$ &, 020 & 801 & ,054 & ,554 \\
\hline & $\mathrm{N}$ & 355 & 355 & 355 & 355 \\
\hline \multirow{3}{*}{$\begin{array}{l}\text { Olumsuz Yeme } \\
\text { Davranışı }\end{array}$} & $\mathrm{R}$ & $153^{\star \star}$ & $157^{\star \star}$ &, 045 & $201^{\star *}$ \\
\hline & $\mathrm{P}$ & ,004 & ,003 & ,400 &, 000 \\
\hline & $\mathrm{N}$ & 355 & 355 & 355 & 355 \\
\hline
\end{tabular}

${ }^{\star} p<, 05 ;{ }^{* *} p<, 01$ 
Tablo 5’e bakıldığında Anne Formu Kontrole Yönelik İlgi alt boyutu puanları ile Olumlu Yeme Davranışı alt boyut puanları arasında "negatif yönlü düşük" düzeyde anlamlı bir ilişki $(\mathrm{r}=-.123, \mathrm{p}<, 05)$; Olumsuz Yeme Davranışı alt boyut puanları ile arasında pozitif yönlü anlamlı bir ilişki $(\mathrm{r}=, 153, \mathrm{p}<, 01)$ görülmektedir. Bu bulgulara göre; aradaki korelasyon düşük seviyede olmasına rağmen annelerin çocuklarını kontrole yönelik ilgi davranışları arttıkça çocukların olumsuz yeme davranışları da artmakta, olumlu yeme davranışları ise azalmaktadır.

Anne Formu Davranış Geliştirmeye Yönelik İlgi alt boyutundan aldınan puanlar ile Olumsuz Yeme Davranışı alt boyutu puanları arasında "pozitif yönlü düşük" düzeyde anlamlı bir ilişki $(r=, 157 ; p<, 01)$ olduğu saptanmıştır. Okula Yönelik İlgi alt boyutundan alınan puanlar ile Çocuklarda Yeme Davranışı Değerlendirme Ölçeğinin alt boyutlarından alınan puanlar arasında anlamlı bir ilişki $(\mathrm{p}>, 05)$ bulunamamıştır. Anne Formu İlgileri Geliştirmeye Yönelik İlgi alt boyutundan alınan puanlar ile Olumsuz Yeme Davranışı alt boyutu puanları arasında "pozitif yönlü düşük" düzeyde anlamlı bir ilişki $(\mathrm{r}=, 201 ; \mathrm{p}<, 01)$ olduğu görülmektedir.

Tablo 6. Çocuklarda Yeme Davranışı Değerlendirme Ölçeği ile Çocuklara Yönelik Anne-Baba İlgisi Ölçeği Baba Formu Puanları Arasındaki İlişki

Pearson

\begin{tabular}{|c|c|c|c|c|}
\hline \multicolumn{2}{|l|}{ Alt Boyutlar } & \multirow{2}{*}{$\begin{array}{c}\begin{array}{c}\text { Davranış Geliştirmeye } \\
\text { Yönelik Îlgi }\end{array} \\
-, 093\end{array}$} & \multirow{2}{*}{$\begin{array}{c}\text { Kontrole Yönelik İlgi } \\
-, 074\end{array}$} & \multirow{2}{*}{$\begin{array}{c}\text { Okula Yönelik İlgi } \\
, 087\end{array}$} \\
\hline \multirow{3}{*}{ Olumlu Yeme Davranışı } & $\mathrm{R}$ & & & \\
\hline & $\mathrm{P}$ &, 082 & , 165 & ,101 \\
\hline & $\mathrm{N}$ & 354 & 354 & 354 \\
\hline \multirow{3}{*}{ Olumsuz Yeme Davranışı } & $\mathrm{R}$ &,- 019 & ,000 &, 045 \\
\hline & $\mathrm{P}$ & ,719 & ,998 & ,400 \\
\hline & $\mathrm{N}$ & 354 & 354 & 354 \\
\hline
\end{tabular}

${ }^{*} p<, 05 ;{ }^{* *} p<, 01$

Tablo 6 incelendiğinde ÇocuklardaYeme Davranışı Değerlendirme Ölçeğinden alınan puanlar ile Çocuklara Yönelik Anne-Baba İlgisi Ölçeği Baba Formu’ndan alınan puanlar arasında istatistiksel olarak anlamlı bir ilişki (p $>, 05)$ olmadığg görülmektedir.

\section{SONUÇ, TARTIŞMA VE ÖNERILLER}

Araştırmanın temel amacı, 5-6 yaş çocuklarının yeme davranışları ile anne-baba ilgisi arasındaki ilişkinin incelenmesidir. Araştırmaya 357 çocuğun anne-babası katılım göstermiştir. Çocukların yeme davranışlarını belirlemek için “Çocuklarda Yeme Davranışı Ölçeği” ile anne-babaların ilgi düzeyini belirlemek için "Çocuğa Yönelik Anne-Baba İlgisi Ölçeği” kullanılmıştır.

Alanyazın incelendiğinde çocukların yeme davranışı ile ilgili çalışmalar bulunmasına rağmen yeme davranışı ile anne-baba ilgisi arasındaki ilişkiyi inceleyen çalışmaya rastlanmamıştır. Benzer konulu kısıtlı araştırmalara ise sonuç ve tartışma kısmında değinilmeye çalışılmıştır.

$\mathrm{Bu}$ araştırmada Çocuklarda Yeme Davranışı Değerlendirme Ölçeğinden alınan puanların ortalama ve standart sapma değerleri incelenmiştir. Elde edilen sonuçlara göre; Olumlu Yeme Davranışı alt boyutundan alınan puanlar en düşük 1,57, en yüksek 5,00'dir; bu alt boyuttan alınan ortalama puanların ise orta düzeydedir. Olumsuz Yeme Davranış1 alt boyutundan alınan puanlar ise en düşük 1,00, en yüksek 3,60'dır ve bu alt boyuttan alınan ortalama puanlar düşük düzeydedir. Yeme davranışı; beslenme ihtiyacı karşılanırken sergilenen tutum ve davranışlardır. Bu davranışlar bireyden bireye farklılık gösterebilir (Karakuş ve diğerleri, 2016). Çocukların gelecek yaşantısı ve toplum sağllğı açısından, okul öncesi dönemde edinilen beslenme davranışları ve alışkanlıkları büyük bir öneme sahiptir (Öztürk ve Türker, 2021). Çocuklar için yemek yeme, kendini yönetebilmek adına kaydettiği önemli bir gelişmedir. Yardımsız yemek yiyebilmesi, özerk olabilmesi adına büyük önem taşımaktadır (Yavuzer, 2016). Vücuda yeterli miktarda ve çeşitlilikte ihtiyacı olan enerji ve besin ögelerinin alınamaması yetersiz ve dengesiz beslenmeye sebep olur (Şanlıer, 2007). Bu da çocuğun büyümesinin yanısıra fiziksel, sosyal ve duygusal gelişimini de olumsuz etkilemektedir. Gelişimin olumlu bir şekilde ilerleyebilmesi için çocuktan sorumlu olan kişinin çocuğun beslenme düzenine ve alışkanlıklarına dikkat 
etmesi ve anlatması gerekmektedir (Kahraman, 2019). Ünlü (2011), Çocuklarda Yeme Davranışı Değerlendirme Ölçeği’nin Türk çocuklarına uyarlanması adlı çalışmasında çocuğun sergilediği olumlu yeme davranışını ailenin gelir düzeyi açısından incelemiş, grupların ortalamaları arasında anlamlı bir fark olmadığını, ancak gelir durumu yüksek olan ailelerin çocuklarının gelir durumu orta ve düşük olan ailelerin çocuklarına kıyasla daha olumlu yeme davranışları sergilediğini belirtmiştir. Özyürek, Belge ve Özkan (2013), okul öncesi dönem çocuklarının beslenmesi konusunda ebeveyn görüşlerini aldıkları çalışma sonucunda annelerin çocuklarının sağlıklı beslenemediğini, kendilerinin çocuklarının sağlıklı beslenmeleri konusunda bilgisiz olduklarını ve beslenme sorunlarının çözümünde desteğe gereksinim duyduklarını dile getirdiklerini ortaya koymuşlardır.

Bu araştırmada Çocuğa Yönelik Anne-Baba İlgisi Ölçeği Anne Formu ile Baba Formu’ndan alınan puanların ortalamaları ve standart sapma değerleri de incelenmiştir. Elde edilen sonuçlara göre; Anne Formu’nun tüm alt boyutlarından alınan ortalama puanlar düşük düzeydedir. Baba Formu’nun iki alt boyutundan alınan ortalama puanlar düşük, sadece Okula Yönelik İlgi alt boyutundan alınan ortalama puanlar orta düzeydedir. Anne-babaların çocuğuna ilgisi; çocuklarına sosyalleşme ve yetiştirilme evresinde destek olması, yardım edici tutum ve davranışlar sergilemesidir, çocukların eğitimsel dönemlerine ve deneyimlerine aktif olarak katılmalarıdır. Ayrıca çocukların başarılı bir eğitim dönemi geçirebilmeleri için ailelerin beklentilerini devam ettirmesi, çocukları ile daha sık iletişim kurması, görüş alışverişi yapması, okula götürmeden önce ödev kontrollerinin yapılması, ailelerin okulda gerçekleşen etkinliklere katılım göstermesi anne-baba ilgisinin boyutları olarak belirtilmektedir (Jeynes, 2007). Okul öncesi dönemde annebaba ilgisi oldukça önemlidir, çünkü çocuk kendisine uyarıcı bir çevre sunan, sevgi gösteren ve sağlıklı gelişimini sağlayan anne-babaya ihtiyaç duyar (Yavuzer, 2001) ve bu dönemde diğer dönemlere göre gelişim daha hızlıdır (Anderson ve Minke 2007; Berthelsen ve Walker 2008; Jeynes, 2011). Çocukların sağlıklı bir şekilde gelişebilmesi için fiziksel olduğu kadar duygusal ihtiyaçlarının da giderilmesi önemlidir. Çocuk ile zaman geçirmek, ilgi göstermek ve sevgiyi hissettirmek duygusal gelişimlerini desteklemektedir. İlginin çocuğun gelişimi üzerinde etkili olabilmesi tutarlı, sürekli ve kaliteli bir şekilde ortaya konulmasına bağlıdır. Çocukluk döneminde ilgiyi göstermenin en kolay yolu ise çocuğun yaşına ve gelişim özelliğine paralel oyunlar oynamaktır (Öztürk, 2007). Bu araştırmalar çerçevesinde bakıldığında okul öncesi dönem çocuklarının yeme davranışlarını etkileyen olumlu-olumsuz etkenler olduğunu, anne-babaların yeme davranışları üzerinde etkili ve önemli bir faktör oluşturduğu, anne-baba ilgisinin çocuğun birçok gelişim alanı açısından destekleyici ve önemli olduğu görülmektedir. Bozok (2017), yaptığı çalışma sonucunda ilgili babaların çocukların gelişimi yönünden daha sağlıklı ve destekleyici olduğunu belirtmiştir. Ayrıca babaların aileleri ve sosyal çevreleri tarafından desteklendiklerinde ilgili babalık davranışlarında olumlu yönde ilerlemeler olduğunu saptamıştır. Babaların ilgilerini etkileyen faktörlerden birini de çalışma koşulları olarak belirtmiş, uzun ve stresli iş hayatına sahip babaların ilgiye yönelik davranışlarını olumsuz yönde etkilediğini vurgulamıştır. Aktaç (2016), okul öncesi dönem çocukları için aile katılımlı beslenme eğitim modelinin geliştirilmesi ve çocukların beslenme bilgi ve davranışları üzerine etkisinin değerlendirilmesi adlı araştırmasında, bazen ve her zaman yemek seçen çocukların istatistiksel oranının \%82,4 olduğunu, okul öncesi eğitime başladıktan sonra bu oranın \%33,8'inin yemek seçiciliğinin azaldığını belirtmiştir.

Bu araştırmada Çocuklarda Yeme Davranışı Değerlendirme Ölçeği’nden alınan puanlar ile Çocuğa Yönelik AnneBaba İlgi Ölçeği Anne Formu’ndan alınan puanlar incelenmiştir. Elde edilen sonuçlara göre; Kontrole Yönelik İlgi alt boyutu puanları ile Olumlu Yeme Davranışı alt boyutu puanları arasında "negatif yönlü düşük" düzeyde anlamlı bir ilişki görülürken, Olumsuz Yeme Davranışı alt boyutu puanları ile "pozitif yönlü düşük" düzeyde anlamlı bir ilişki vardır. Davranış Geliştirmeye Yönelik İlgi alt boyutundan alınan puanlar ile Olumsuz Yeme Davranışı alt boyut puanları arasında "pozitif yönlü düşük" düzeyde anlamlı bir ilişki olduğu da saptanmıştır. İlgileri Geliştirmeye Yönelik İlgi alt boyutundan alınan puanlar ile Olumsuz Yeme Davranışı alt boyutu arasında "pozitif yönlü düşük" düzeyde anlamlı bir ilişki olduğu belirlenmiştir. Bu sonuçlara göre annelerin kontrole yönelik ilgisi, ilgilerini geliştirmeye yönelik ilgisi ve davranış geliştirmeye yönelik ilgisi arttıkça çocuklardaki olumsuz yeme davranışları da artmaktadır, yani annelerin kontrole, davranışa ve ilgilerini geliştirmeye yönelik ilgili olmasının çocuğun yeme davranışlarını olumsuz etkilediği söylenebilir. Bunun nedeni, annenin aşırı ilgisine çocuğun olumsuz yeme davranışı ile tepki göstermesi olabilir. Alanyazın incelendiğinde konuyla doğrudan örtüşen çalışmalara rastlanmamakla birlikte farklı yönlerden ele alan çalışmalar bulunmaktadır. Ogelman (2013), annelerin otoriter tutumları arttıkça, çocukların sosyal becerilerini geliştirme ve okula uyum düzeylerinin azaldığını belirtmiştir. Tuzcuoğlu ve diğerleri (2020), çalışmaları sonucunda annelerin ilgisi arttıkça çocuklardaki saldırganlık yönelimlerinin azaldığını belirtmişlerdir.

Araştırmada, Çocuklarda Yeme Davranışı Değerlendirme Ölçeği’nden alınan puanlar ile Çocuğa Yönelik AnneBaba İlgi Ölçeği Baba Formu’ndan alınan puanlar da incelenmiştir. Sonuçlara bakıldığında sadece Okula Yönelik İlgi alt 
boyutu ile Olumlu Yeme Davranışı alt boyut puanları arasında "pozitif yönlü düşük" düzeyde anlamlı bir ilişki olduğu görülmektedir, yani babaların okula yönelik ilgilerinin çocuklarının yeme davranışlarını da olumlu yönde etkilediği düşünülebilir. Hill ve Tyson (2009) yaptıkları çalışmada, anne-babaların çocuklarının okulu ile ilgilenmesi, gönüllü olarak okul aktivitelerine katılması ile çocuğun okul başarısı arasında anlamlı bir ilişki olduğunu vurgulamaktadır. Yine benzer sonuçlara ulaşan Carter (2003), çocukların okul ile alakalı etkinliklerine aktif olarak katılan babaların çocukların okula yönelik daha olumlu tutum sergilemesine, evde ve okul hayatında kendi sorumluluklarını yerine getirmesinde etkili olduğunu savunmaktadır. Green (2001), çocuk ile baba arasında kurulan sıcak ilişkinin, eğitimlerine aktif olarak katılmalarının çocuğun kendine güveninde, akranları ile iyi ilişkiler kurabilmesinde, okulda başarılı olabilmesinde, cinsiyet rollerinin sağlıklı bir şekilde gelişmesinde, ekonomik kaynakları iyi bir şekilde kullanmada etkili olduğunu vurgulayarak benzer sonuçları desteklemektedir. Amato (1994) ise çocuklukta babası ile pozitif ve yakın ilişkiler içinde olan çocukların yetişkinlikte eğitim düzeyinin, iş hayatının, psikososyal durumunun olumlu yönde etkilendiğini ortaya koymaktadır, yani baba ile oluşturulan olumlu ilişkilerin çocuğun tüm hayatını etkilediği vurgulanmıştır. Dolayısı ile çocuk üzerinde baba ilgisinin çocuğun davranışları, başarısı, gelişimi üzerinde etkili olduğu yapılan çalışmalarla desteklenmektedir. Yapılan bu çalışma ile baba ilgisinin etkili olduğu davranışlardan birinin de çocuğun yeme davranışı olduğu söylenebilir.

- Araştırmadan elde edilen bulgular ışı̆̆ında şu öneriler geliştirilebilir:

- Araştırmaya dahil edilen çocukların yaş ranjı genişletilerek sonucun farklılaşıp farklılaşmadığı incelenebilir.

- Anne ve babalara açık uçlu sorular yöneltilerek farklı yeme davranışlarını da dile getirmeleri sağlanabilir.

- Araştırma okul öncesi eğitim kurumuna devam eden çocuklarla yapıldığından, çocukların öğretmenlerinin de görüşlerinin alındığ farklı bir çalışma düzenlenebilir.

- Okul öncesi eğitim kurumuna gitmeyen çocuklarla da benzer bir araştırma gerçekleştirilebilir.

\section{KAYNAKÇA}

Ak, M. (2018). Illkokul kademesindeki öğrencilerin ebeveynlerine verilecek olan 3 adım anne babalıkta ustalaşma eğitim programının çocuğa yönelik anne-baba ilgisi üzerindeki etkisinin incelenmesi (Yüksek lisans bitirme projesi). Ege Üniversitesi, Sosyal Bilimler Enstitüsü, İzmir.

Aktaç, Ş. (2016). Okul öncesi çağ çocuklar için aile katılımlı beslenme eğitim modelinin geliştirilmesi ve çocukların beslenme bilgi ve davranışları üzerine etkisinin değerlendirilmesi (Yayınlanmamış doktora tezi). Başkent Üniversitesi, Sağlık Bilimleri Enstitüsü, Ankara.

Amato, P. R. (1994). Father-child relations, mother-child relations, and offspring psychological well-being in early adulthood. J Marriage Fam, 56(4), 1031-1042.

Anderson, K. J. ve Minke, K. M. (2007). Parent involvement in education: Toward an understanding of parents' decision making. The Journal of Educational Research, 100(5), 311-323.

Arabacı, N. ve Ömeroğlu, E. (2013). 48-72 aylık çocuğa sahip anne-babaların çocukları ile iletişimlerinin bazı değişkenler açısından incelenmesi. Selçuk Üniversitesi Sosyal Bilimler Enstitüsü Dergisi, 30, 41-53.

Arlı, M., Şanlıer, N., Küçükkömürler, S. ve Yaman, M. (2017). Anne ve çocuk beslenmesi. (8. bs.). Ankara: Pegem Akademi.

Baştürk, S., ve Taştepe, M. (2013). Evren ve örneklem. S. Baştürk (Ed.), Bilimsel araştırma yöntemleri. Ankara: Vize Yayıncılık.

Berthelsen, D. ve Walker, S. (2008). Parent involvement in their children's educations. Family Matters, 79, 34-41.

Bozok, M. (2017). Türkiye'de babalı̆̆ı anlamak serisi-I. Özel Araştırma Raporu. İstanbul.

Büyüköztürk, Ş. (2017). Bilimsel araştırma yöntemleri. (23. bs.). Ankara: Pegem Akademi.

Carter, S. (2003). Educating our children together: Source book for effective family - school comminity partnerships. U.S. Office of Special Educational Programs.

Coleman, P. K. ve Karraker, K. H. (2000). Parenting self-efficacy among mothers of school-age children. Conceptualization, Measurement, and Correlate, 49(1), 13-24. Erişim adresi: https://doi.org/10.1111/j.1741-3729.2000.00013.x.

Çelikoyar, Z. (1988). Sosyo-ekonomik düzeyi düsük bir grup kentsel çocuğun beslenme ve gelişim durumları (Yüksek lisans tezi). İstanbul Üniversitesi, Çocuk Sağlığı Enstitüsü, İstanbul.

Ek, A., Sorjonen, K., Eli, K., Lindberg, L., Nyman, J., Marcus, C. ve Nowicka, P. (2016). Associations between parental concerns about preschoolers' weight and eating and parental feeding practices: results from analyses of the child eating behavior 
questionnaire, the child feeding questionnaire, and the lifestyle behavior checklist. Plos One, 11(1), 1-20. Erişim adresi : doi:10.1371/journal.pone.0147257

Englund, M. M, Luckner, A. E., Whaley, G. J. L. ve Egeland, B. (2004). Children's achievement in early elementary school: Longitudinal effects of parental involvement, expectations, and quality of assistance. Journal of Educational Psychology, 96(4), 723-730.

Erdoğdu, Ö. ve Çetkinkaya Ş. (2019). 5-6 yaş grubu çocuklarda ebeveyn tutumlarının akran ilişkilerine etkisi (Yüksek lisans tezi). Çukurova Üniversitesi, Sağlık Bilimleri Enstitüsü. İstanbul.

Erol, E. T. (2019). Anne-baba tutumları ile 5-10 yaş grubu çocukların davranışları arasındaki ilişkinin incelenmesi (Yüksek lisans tezi). İstanbul Aydın Üniversitesi, Sosyal Bilimler Enstitüsü. İstanbul.

Fan, X. T. ve Chen, M. (2001). Parental involvement and students' academic achievement: A meta analysis. Educational Psychology Review, 13(1), 1-22.

Garipağaoğlu, M., Saydam, R. ve Gökçay, G (2003). Beslenme sorunu olan çocuklara ekip yaklaşımının sonuçları. 47. Milli Pediatri Kongresi, 3. Milli Çocuk Hemşireliği Kongresi 2. Pediatri Asistanları Kongresi Bilimsel Program ve Özet Kitabı, İstanbul.

Georgiou, St. ve Tourva, A. (2007). Parental attributions and parental involvement. Social Psychology of Education, 10(4), 473-482.

Green, S. (2001). Creating a father friendly child care environment. Child Care Centers Conections. 10(1), 1-4 . Erişim adresi: https://www.fatherhood.gov/sites/default/files/ Resource\%20Files/e000000534_0.pdf.

Günindi, N. (2008). Okul öncesi eğitim kurumlarına devam eden altı yaş çocuklarının sosyal uyum becerileri ile anne-babalarının empatik becerileri arasındaki ilişkinin incelenmesi (Yayımlanmamış yüksek lisans tezi). Gazi Üniversitesi, Eğitim Bilimleri Enstitüsü, Ankara.

Hamamcı, Z. (2005). Üç-altı yaşlarında çocukları olan anne ve babaların aile eğitim ihtiyaçlarının belirlenmesi. Çă̆daş Eğitim Dergisi, 30, 319. Erişim adresi: http://www.cagdasegitim.org/?set=aylik\&arsiv=200504.

Hill, N. E. ve Craft, S. A. (2003). Parent-school involvement and school performance: mediated pathways among socioeconomically comparable African American and Euro-American families. Journal of Educational Psychology, 95(1), 74-83. Erişim adresi: https://doi.org/10.1037/0022-0663.95.1.74.

Hill, N. E. ve Tyson, D. F. (2009). Parental involvement in middle school: A meta-analytic assessment of the strategies that promote achievement. Developmental Psychology, 45(3), 740-763. Erişim adresi: https://doi.apa.org/doiLanding?doi $=10.1037 \% 2 \mathrm{Fa} 0015362$.

İnci, M. A. ve Deniz, Ü. (2015). Baba tutumları ile çocuğun yaşı, cinsiyeti, doğum sırası ve kardeş sayısı değişkenleri arasındaki ilişkinin incelenmesi. Karadeniz Sosyal Bilimler Dergisi, 7(2).

Jeynes, W. H. (2007). The relationship between parental involvement and urban secondary school student academic achievement: A meta-analysis. Urban Education, 42(1), 82-110.

Kahraman, D. (2019). Okul öncesi dönem çocuklarının yeme davranışlarının değerlendirilmesi (Yüksek lisans tezi). Kırklareli Üniversitesi, Sağlık Bilimleri Enstitüsü, Kırklareli.

Karakuş, S. Ş., Yıldırım, H. ve Büyüköztürk, Ş. (2016). Üç faktörlü yeme ölçeğinin Türk kültürüne uyarlanması: Geçerlik ve güvenirlik çalışması. TAF Preventive Medicine Bulletin, 15(3), 229-237. Erişim adresi: DOI: 10.5455/pmb.1-144.654.0396.

Kim, E. (2002). The relationship between parental involvement and children's educational achievement in the Korean immigrant family. Journal of Comparative Family Studies, 33(4), 529-543.

Köroğlu, S. (2009). Okul öncesi dönem 4-6 yaş arası çocuklarda aileden kaynaklanan beslenme bozukluklarının incelenmesi (Yüksek lisans tezi). Selçuk Üniversitesi. Sosyal Bilimler Enstitüsü, Konya.

Ogelman, H. G., Önder, A., Seçer, Z. ve Erten, H. (2013). Anne tutumlarının 5-6 yaş çocuklarının sosyal becerilerini ve okula uyumlarını yordayıcı etkisi. Selçuk Üniversitesi Sosyal Bilimler Enstitüsü Dergisi, 29, 143-152.

Öngider, N. (2006). Evli ve boşanmış ailelerde algılanan ebeveyn kabul veya reddinin çocuğun psikolojik uyumu üzerindeki etkileri (Doktora tezi). Ege Üniversitesi, Sosyal Bilimler Enstitüsü, İzmir.

Öztürk, M. (2007). Anne, baba ve eğitimciler için çocuk psikiyatrisi. İstanbul: Uçurtma Yayınları.

Öztürk, N., ve Türker, P. F. (2021). Okul Öncesi Dönemde Çocuklardaki Farklı Yeme Davranışları ve Ebeveyn Faktörlerinin Bu Davranışlara Etkisi. Başkent Üniversitesi Sağlık Bilimleri Fakültesi Dergisi-BÜSBİD, 6(1), 1 - 14.

Özyürek, A. ve Tezel Şahin, F. (2005). 5-6 yaş grubunda çocuğu olan ebeveynlerin tutumlarının incelenmesi. Gazi Eğitim Fakültesi Dergisi, 25(2), 19-34. 
Özyürek, A., Begde Z. ve Özkan, İ. (2013). Okul öncesi dönem çocukların beslenmesi konusunda ebeveyn görüşlerinin belirlenmesi. Uluslararası Hakemli Beşeri ve Akademik Bilimler Dergisi, 2(4), 130-144.

Sak, R., Şahin Sak, İ.T., Atlı, S. ve Şahin. B.K., (2015). Okul öncesi dönem: anne baba tutumları. Mersin Üniversitesi Eğitim Fakültesi Dergisi, 11(3), 972-991. Erişim adresi: https://doi.org/10.17860/efd.33313.

Seçer, Z., Çeliköz, N. ve Songül, Y. (2008). Okul öncesi eğitim kurumlarına devam eden çocukların annelerinin ebeveynliğe yönelik tutumları. Selçuk Üniversitesi Sosyal Bilimler Enstitüsü Dergisi, 19, 413-428.

Sevinç, M. (2006). Okul öncesi eğitim alan çocukların annelerinin okuldan beklentileri. Kazım Karabekir Eğitim Fakültesi Dergisi, 0(13), 218-225. Erişim adresi: https://dergipark.org.tr/tr/pub/ataunikkefd/issue/2774/37158.

Shapiro, A. D. (1996). Marital status transitions, father-child relationships, and fathers' psychological well-being (Doctoral dissertation). University of Texas, Austin.

Sucuoğlu, H., Özkal, N., Yıldız Demirtaş, V. ve Güzeller, C. O. (2015). Çocuğa yönelik anne-baba ilgisi ölçeğinin geliştirme çalışması. Abant İzzet Baysal Üniversitesi Eğitim Fakültesi Dergisi, 15(1), 242-263. Erişim adresi: https://doi.org/10.17240/ aibuefd.2015.15.1-500.012.8605.

Şahin, F. T. ve Özyürek, A. (2008). 5-6 yaş grubu çocuğa sahip ebeveynlerin demografik özelliklerinin çocuk yetiştirme tutumlarına etkisinin incelenmesi. The Journal of Turkish Educational Sciences, 6(3), 395-414. Erişim adresi: https://dergipark.org.tr/tr/ pub/tebd/issue/26111/275098.

Tezel Şahin, F. (2003). Çocuğun gelişimi ve eğitiminde babanın rolü. Erken çocuklukta gelişim ve eğitimde yeni yaklaşımlar. M. Sevinç (Ed.), İstanbul: Morpa Kültür Yayınları.

Tudge, J., Hogan, D., Snezhkova, I., Kulakova, N. ve Etz, K. (2000). Parent's child-rearing values and beliefs in the United States and Russia: The impact of culture and social class. Infant and Child Development, 9(2), 105-121. Erişim adresi: https://doi. org/10.1002/1522-7219(200006)9:2\%3C105::AID-ICD222\%3E3.0. CO;2-Y

Tunalı, D. (2019). Ebeveynlerin özel kreş ve anaokulu tercihine yönelik tutumlarının konjoint analizi ile incelenmesi. Akademik Araştırmalar ve Çalışmalar Dergisi (AKAD), 11(20), 162-171. Erişim adresi: https://doi.org/10.20990/kilisiibfakade mik.446773.

Tuzcuoğlu, N., Cengiz, Ö. ve Küsmüş, G. İ. (2020). Okul öncesi dönem çocuklarının saldırganlık yönelimleri ile annelerinin ilgi düzeylerinin belirlenmesi. Erken Çocukluk Çalışmaları Dergisi, 4(1), 3-28.

Uzun, H. ve Baran, G. (2019). Babaların okul öncesi dönemdeki çocuklarıyla ilişkisinin bazı değişkenlere göre incelenmesi. Mersin Üniversitesi Eğitim Fakültesi Dergisi, 15(1), 47-60.

Ünlü, H. (2011). Okul öncesi dönem çocuklar için yeme davranışı değerlendirme ölçeğinin Türk çocuklarına uyarlanması (Yüksek lisans tezi). Marmara Üniversitesi, Eğitim Bilimleri Enstitüsü, İstanbul.

Wisner, L., Peindl, S. ve Hanusa H. (1996). Effect child bearing on the natural history of panic disorder with comorbid mood disorer. J Affect Disord., 41(3), 173-180. Erişim adresi: https://doi.org/10.1016/S0165-0327(96)00069-9.

Yavuzer, H. (2001). Bedensel, zihinsel ve sosyal gelişimiyle çocuğunuzun ilk 6 yılı. İstanbul: Remzi Kitabevi.

Yavuzer, H. (2011). Çocuk psikolojisi. (33. bs.). İstanbul: Remzi Kitabevi.

Yavuzer, H. (2016). Ana-baba ve çocuk. İstanbul: Remzi Kitabevi. 


\title{
Examination of the Relationship Between Eating Behaviors of 5-6 Years Old Children Attending Pre-School Institutions and Mother-Father Child Care Level
}

\author{
Nur Betül KARAASLAN (iD, Hülya BİLGíN (iD
}

\section{Introduction and Purpose}

The research aims to examine the relationship between the eating behaviours of 5-6 years old children and the parents' child care levels with the data obtained from the parents of 5-6 years old preschool children attending preschool education institutions.

\section{Literature Review}

The attitude of parents has great importance for preschool children to have regular eating habit (Köroğlu, 2009). This is because during this period, children are still dependent on their parents in food intake (Annex, 2016). Children acquire socio-cultural values and nutritional habits from their families, which they will carry their traces throughout their lives. Therefore, it is possible to evaluate the eating habits of the child by looking at the lifestyle of the parents (Wisner, 1996). On the other hand, it is also emphasized that the child is affected behaviorally and academically by the parent's care (Chen \& Fan 2001; Craft \& Hill 2003; Englund et al., 2004; Jeynes, 2007; Kim, 2002). Considering that parents have an undeniable effect on the child and the child behaviors, it is thought that there would be a relationship between children's eating behaviors and parents' care levels. The problem sentence of the study is to examine the relationship between the eating behaviors of 5-6 year old children attending preschool education institutions and their parents' care levels.

\section{Methodology}

The sample of the study consists of mothers and fathers of 357 children in the 5-6 age group who attend private / public preschool education institutions affiliated to the Ministry of National Education in Istanbul in the 2017-2018 academic year. In the research, relational screening method was used. The "Personal Information Form" prepared by the researcher in order to find, children and parents' demographic characteristics and "Children Eating Behaviour Evaluation Scale" prepared by Lynda A. Archer, Peter L. Rosenbaum, David L. Streiner (1990) and translated by Ünlü (2011) in order to find children eating behaviour used in the research. The Cronbach's Alpha values were found as 0.81. "Mother-Father Child Care Scale" created by Sucuoğlu, Özkal, Yıldız-Demirtaș and Güzeller (2015) was used in the research in order to determine mother-father child care scale. The Cronbach's Alpha coefficient for the mother's care is 0.91 and 0.94 for the father's care. In regards to data analysis, Independent Groups $\mathrm{T}$ Test, The One-Way Analysis of Variance (ANOVA) and Mann Whitney-U test were used.

\section{Result, Conclusion and Suggestions}

According to the results of the research: It is observed that there is a "low" correlation between the Child Eating Behavior Evaluation Scale and the Mother-Father Child Care Scale. According to this relationship, while negative "low" level correlation has found between the mothers' sub-dimension control scores and children's positive eating behavior scores $(\mathrm{r}=-, 123 ; \mathrm{p}<.05)$, it is observed that there is a positive "low" level correlation between the mothers' sub-dimension control scores and the negative eating behavior scores, $(\mathrm{r}=, 153 ; \mathrm{p}<.01)$. It is also observed that there is a positive "low" level correlation $(\mathrm{r}=, 157 ; \mathrm{p}<.01)$ between the scores of the mothers' sub-dimension care scores in behavior development and the children's negative eating behavior scores. Additionally, it is observed that there is a 
positive "low" level correlation $(\mathrm{r}=, 201 ; \mathrm{p}<.01)$ between mothers' sub-dimension in care development and children's negative sub-dimension eating behavior.

Between the Child Eating Behavior Evaluation Scale and the Mother-Father Child Care Scale for the father; it is observed that there is a positive "low" level correlation $(\mathrm{r}=, 120 ; \mathrm{p}<.05)$ in child sub-dimension school interest with mother's sub-dimension opinion about child's eating behavior.

Although there are studies on eating behavior, there is no study examining the relationship between eating behavior and parental care. For this reason, it is thought that the research will contribute to the literature. Research results expected to contribute to the studies about the effects of parents and parental care on the eating behaviors of the child.

According to the results of the study, the following suggestions can be developed: It can be examined whether the result differs by expanding the age range of the children included in the study. Mothers and fathers may be asked open ended questions to express different eating behaviors. Since the research is conducted with children attending preschool education institutions, a different study can be organized in which the opinions of the teachers of the children are also taken. A similar research can be conducted with children who do not attend pre-school education institutions. The awareness of parents can be increased by explaining the importance of parental care on the development of the child by educators.

Keywords: Pre-school Child, Child Eating Behaviour, Mother-Father Child Care 